DAG RETSÖ

https://orcid.org/0000-0002-0128-0257

Stockholm University

\title{
TERRITORIAL FISCAL SYSTEMS IN MEDIEVAL SWEDEN*
}

Zarys treści: W artykule przedstawiono ewolucję terytorialnych systemów skarbowych w średniowiecznej Szwecji. Opisano długoterminowe trudności finansowe, które zmusiły Koronę do zastosowania wielu strategii fiskalnych, przedstawiono również chronologiczny podział (na pięć faz) zasad funkcjonowania polityki terytorialnej i fiskalnej. Z przeprowadzonej analizy wynika, że równowagę budżetową udało się osiagnąc jedynie w kilku krótkich okresach, ale też państwo potrafiło efektywnie radzić sobie z walką z deficytem budżetowym, przy jednoczesnych naciskach ze strony szlachty i chłopstwa. Uwidoczniło się to zwłaszcza w decyzji o wprowadzeniu niskich podatków, podjętej po udanej rebelii Olava Engelbrektssona w latach 1434-1436. W artykule nie podjęto jednak próby przeprowadzenia ilościowej analizy poziomu dochodów szwedzkiej Korony.

The content outline: This article provides an overview of the evolution of territorial fiscal systems in medieval Sweden. It is shown that persistent financial strains forced the Crown to implement a whole range of fiscal strategies. A rough five-stage chronology of different territorial and fiscal policies is presented. It demonstrates that a budget balance was never really achieved except for short periods, but also that the combined challenge of budget deficits and political pressures from the nobility and the peasantry were handled quite diligently. That was especially the case during the low-tax regime established by the Engelbrekt uprising in 1434-1436. No attempt was made in the article to assess the level of income of the Swedish Crown in quantitative terms.

Słowa kluczowe: podatki, średniowiecze, finanse Korony Szwedzkiej, lenno, organizacja terytorialna

* This paper was supported by Jan Wallanders och Tom Hedelius stiftelse, Handelsbankens forskningsstiftelser [grant number P17-0177] and by Stockholm University. 
Keywords: taxes, Middle Ages, Sweden, Crown finances, fiefs, territorial organization

\section{In the Beginning}

Territorial taxes in Sweden were only established in the $13^{\text {th }}$ century. Before that, the income of the Swedish Crown consisted primarily of agrarian produce from Crown estates around the realm, collectively called Uppsala öd, apart from some smaller revenues from fines and customs duties. The yields from the royal estates were consumed directly by the court in their itinerant governance. The peasants were only required to render military service on the king's warships (ledung), which were occasionally sent out for plundering on the eastern shores of the Baltic Sea, a remnant of a tradition of the Viking age. In addition, the peasants payed a tax in kind (skeppsvist) for the maintenance of the peasant naval militia. However, even this naval military duty was only required of peasants in the coastal areas of southern Sweden, located along the Baltic Sea.

In the $13^{\text {th }}$ century, the conditions began to change. Crown incomes turned out to be insufficient due to raised expenses, caused mainly by changes within the fields of military organization and technology. The peasant militias were replaced by armed knights as the mainstay of the military forces, and fortified castles, built at strategic points around the realm, became the strategic backbone of defense. This changed the nature, size and form of the royal income. The peasants were now freed from military service in the navy, except for certain exceptional occasions, and instead they were required to pay regular taxes. The hitherto occasional maintenance tax skeppsvist was transformed into a permanent liability, as was the naval military service itself (ledungslama). External exploitation of foreign shores had been substituted by internal exploitation of domestic peasants. ${ }^{1}$

The incomes from the old Crown domains were supplanted by general, permanent taxes. As in the rest of Europe, the most important of these derived from agricultural production and were based on the principle of territoriality, i.e. areally determined revenue districts (län, fögderier) whose inhabitants were required to pay a determined sum

${ }^{1}$ For a Marxist view on this transformation, see Th. Lindkvist, "Taxation Systems in Medieval Sweden," in Taxes, Tributes and Tributary Lands in the Making of Scandinavian Kingdoms in the Middle Ages, ed. S. Imsen, Trondheim, 2011, pp. 265-278. 
collected by a special official, a bailiff. From the fiscal point of view the realm was thus divided into a number of geographical fiscal districts, and by the mid-1200s regular taxes had already become the most important source of revenue for the Crown. Initially, the new fiscal organization probably improved its financial situation substantially. The castles, built on the initiative of the Crown, were considered state property, and all collectable taxes quite naturally belonged to the royal Treasury. ${ }^{2}$

Ironically though, the attempts to achieve an improved budgetary situation soon led to the opposite. Under the pressure of continued and even worsening financial problems, the territorial tax system underwent two major changes, a result of both diminished income and rising costs. On the income side, the monarchs were forced to free the armed knights from their tax duties as a compensation for their service to the king, as was already the case with the Church for its religious service, and grant them the status of tax-exempt nobility. The establishment of the Swedish noble class was confirmed in the Alsnö statute of c. $1279 .{ }^{3}$ In addition, the monarchs were to an increasing extent forced to surrender substantial parts of remaining regular tax income due to the institution of fiefs, i.e. royal grants of territorial tax revenue in a particular tax district (förläning) to prominent members of the nobility, which meant a further reduction of tax income for the Crown. This twofold loss of regular taxes forced the Crown to resort to other sources of revenue in the following centuries. Some of the theoretical options available to ease the budget deficits were clearly based on the territorial principle (additional taxes, raised regular taxes, increased use of private incomes in public finances, reduction of seigneurial land) while others were not (debasement of the currency, loans from abroad or from local merchants, commercialization of taxes in kind on the international market, raised customs duties). Most of these measures were either politically or economically inviable and the history of the administration of taxes imposed by Swedish medieval regents is one of a continuous and delicate balancing act.

The main reason for the rising costs was the building of the castles themselves in a relatively short time span from the mid-1200s to the

2 The Swedish territorial fiscal organization during the Middle Ages has been covered by B. Fritz, Hus, land och län: Förvaltningen $i$ Sverige 1250-1434, vol. 1-2, Stockholm, 1972-1973, and D. Retsö, Länsförvaltningen i Sverige 1434-1520, Stockholm, 2009.

${ }^{3}$ S.U. Palme, "Les impôts, le statut d'Alsnö et la formation des ordres en Suède (1250-1350)," in: Problèmes de stratification sociale: Actes de colocque (1966), ed. R. Mousnier, Paris, 1968, pp. 55-71. 

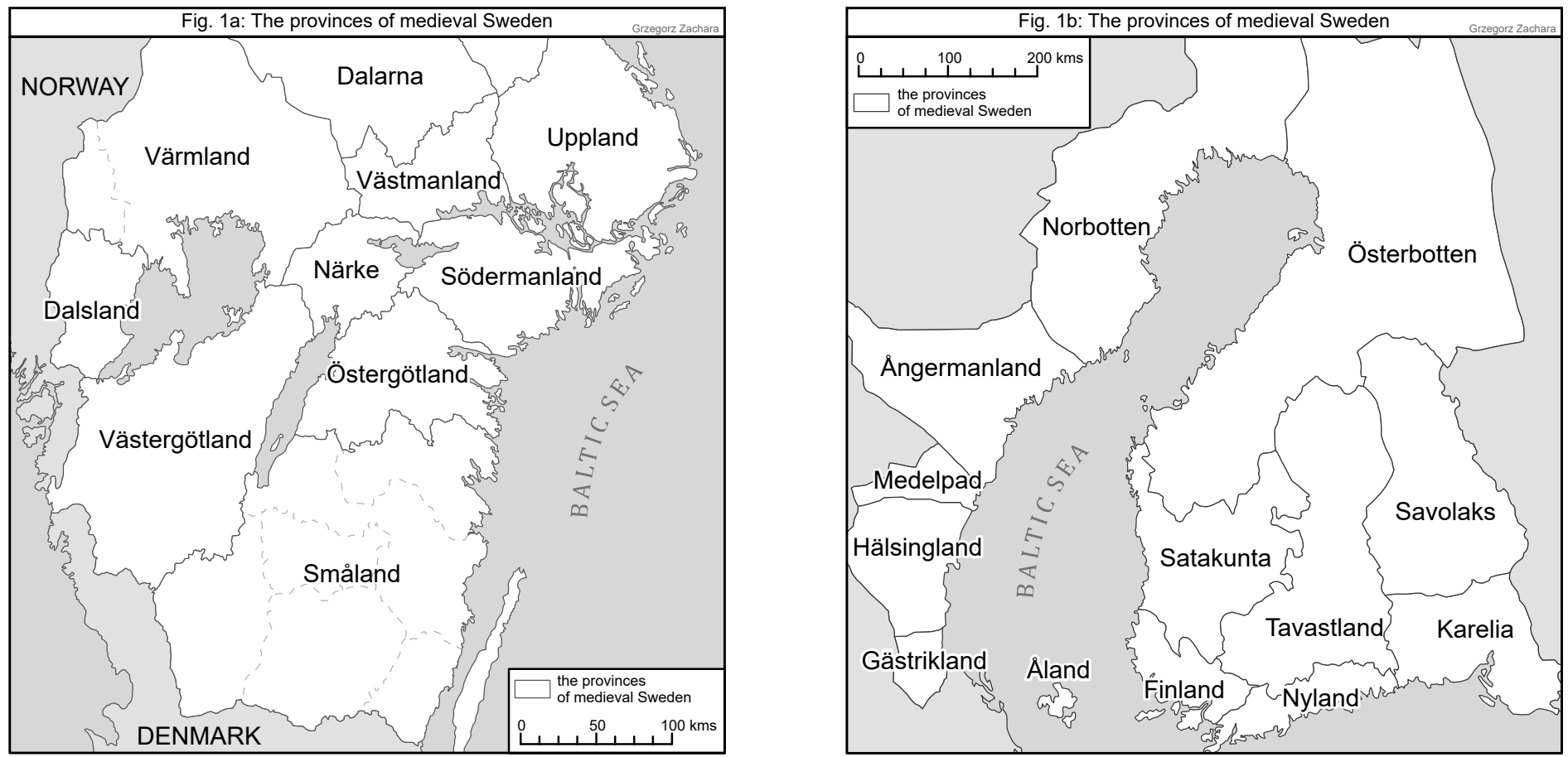

Fig. 1. The provinces of medieval Sweden, incl. Finland 

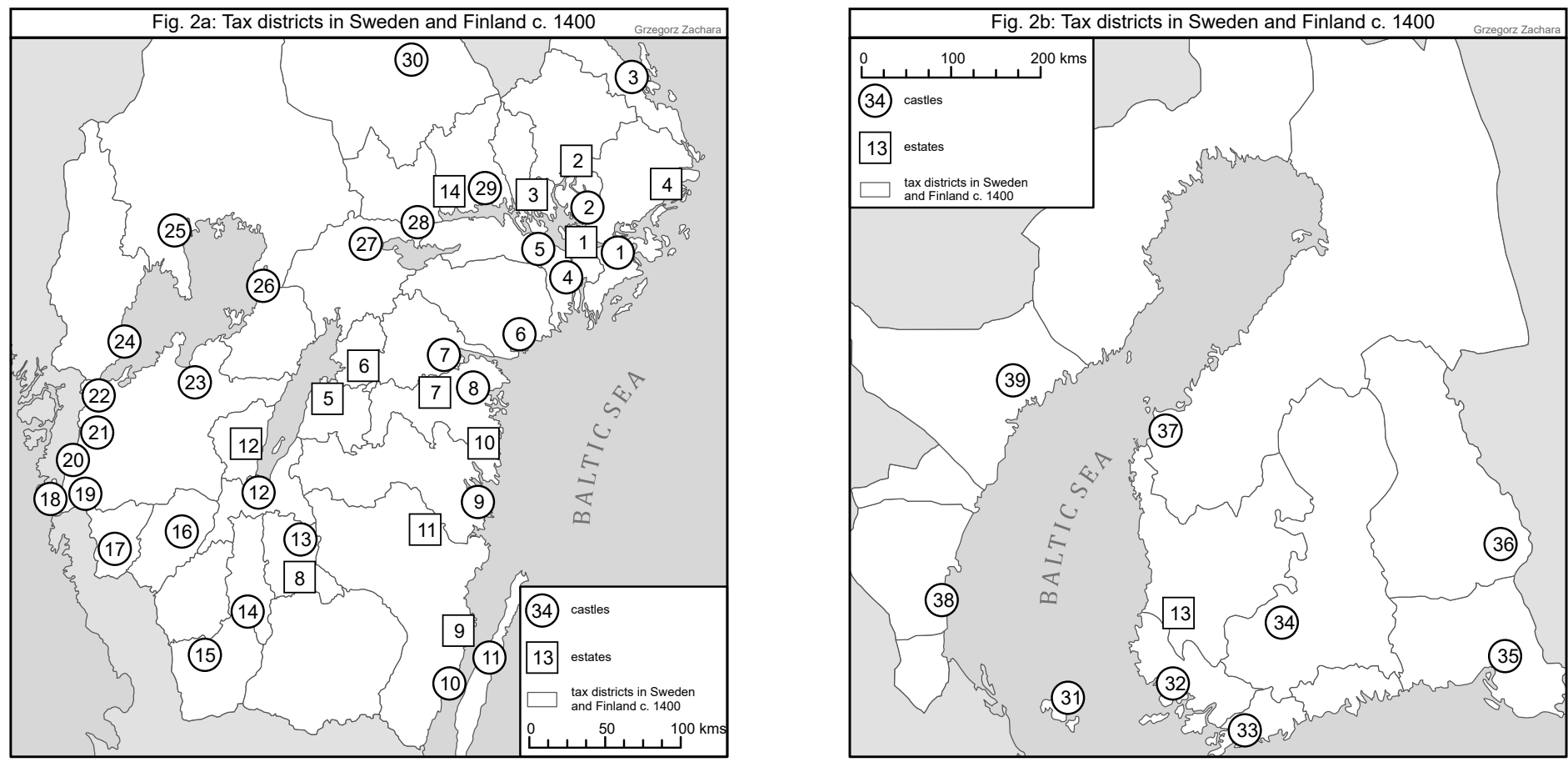

Fig. 2. Tax districts in Sweden and Finland c. 1400

Legend: castles (numbers in circles): 1. Stockholm (c. 1250), 2. Almarestäket (before 1388), 3. Östhammar (1390s), 4. Täljehus (before 1400), 5. Gripsholm (1381), 6. Nyköping (before 1305), 7. Ringstadaholm (before 1310), 8. Stäkeborg (early 1200s), 9. Stäkeholm (before 1370), 10. Kalmar (before 1270s), 11. Borgholm (before 1285), 12. Rumlaborg (1360s), 13. Sundholm (before 1374), 14. Trolleborg (before 1367), 15. Piksborg (1370s), 16. Opensten (late 1300s), 17. Öresten (before 1370), 18. Älvsborg (before 1366), 19. Lindholm (before 1330s), 20. Stynsborg (before 1396), 21. Lödöse (before 1270s), 22. Ekholm (before 1378), 23. Axvall (before 1315), 24. Dalaborg (before 1300), 25. Edsholm (before 1397), 26. Amneholm (before 1371), 27. Örebro (before 1364), 28. Köpingshus (before 1375), 29. Västerås (before 1396), 30. Borganäs (c. 1390), 31. Kastelholm (1380s), 32. Åbo (Turku) (late 1200s), 33. Raseborg (1370s), 34. Tavastehus (late 1200s), 35. Viborg (1293), 36. Olofsborg (1475), 37. Korsholm (before 1384), 38. Faxeholm (before 1398), 39. Styresholm (before 1398); estates (numbers in squares): 1. Svartsjö, 2. Uppsala, 3. Haga, 4. Penningby, 5. Hov, 6. Ulvåsa, 7. Eknäs, 8. Eksjö, 9. Kråkerum, 10. Fågelvik, 11. Tuna, 12. Ettak, 13. Kumogård, 14. Dåvö 
mid-1300s. ${ }^{4}$ They were of course mainly intended for defense purposes, but their emergence was simultaneous with and directly connected to the reform and expansion of the tax system as they replaced the old royal estates as administrative/fiscal centers. Once built, the castles were dependent on taxes from the surrounding fiscal district for the maintenance of their physical premises and their crews.

The geographical definition of fiscal units was based on existing territorial division systems. In principle, the ecclesiastical structure of dioceses and parishes as well as the secular judicial structure of law districts or provinces (landskap, land) and counties or 'hundreds' (härader) could be utilized. The guiding principle was economic viability; the surrounding tax district should simply be big enough to support a castle's expenses. The result was a close correlation between demographical density - and thereby its fiscal capacity - and the size of the castle tax district. Consequently, in some more densely populated areas tax districts were delineated on the basis of other, smaller existing territorialities below the provincial level, i.e. the judicial units of hundreds (härader) and, later, the ecclesiastical units of parishes. This became particularly the case in the course of the $14^{\text {th }}$ century in the demographically dense areas around Lake Mälaren and in Västergötland, where several castles were built. In contrast, in the more sparsely populated areas in northern Sweden and in Finland the tax districts were truly large. For example, the Korsholm castle in Finland had a fiscal area covering well over 160,000 sq km on both sides of the Bay of Bothnia.

\section{The Partitions of the Realm in the $14^{\text {th }}$ Century}

In spite of the initial military criteria for the establishment of the territorial tax system and the economic principle of viability, other factors came to influence its geographical structure, mainly domestic politics. This was especially serious during the reign of King Birger Magnusson (1290-1321), when the realm was ravished by conflicts and civil wars between the King on the one side and his brothers Valdemar and Erik on the other. In the course of events the King had to grant them duchies (Finland and the province of Södermanland, respectively) with concomitant tax rights, and the realm was in effect partitioned. In the first treaty of 1310 , the dukes were granted the Stockholm district,

${ }^{4}$ A detailed analysis of medieval castles in Sweden is included in Ch. Lovén, Borgar och befästningar $i$ det medeltida Sverige, Stockholm, 1996. 
southern and western Sweden as well as all of Finland, including the castles of Stockholm, Kalmar, Axvall, Lödöse, Åbo and Tavastehus (Fig. 3). King Birger's portion was limited to the castle districts of Nyköping, Stäkeborg, Viborg and Närke, and portions of the provinces of Uppland and Småland. In 1315 the dukes divided between them their common possessions so that Erik got western and southeastern Sweden and most of Finland while Valdemar got the Stockholm district, with some exceptions, and the Åbo and Tavastehus districts in Finland (Fig. 4). The 1310 partition came to an end with the imprisonment of the dukes in 1317 and the unity of the realm under one regent was restored with the exception of the Dåvö estate with a large tax district in central Sweden, held by the queen widow Helvig of Holstein until her death in the mid-1320s.

In 1356, a rebellion against King Magnus Eriksson (1332-1365) led by his own son Erik Magnusson broke out and led to a new partition of the kingdom. The following year King Magnus was forced to grant Erik a great part of central and western Sweden and the right to entitle himself king, while he retained southeastern Sweden and Finland (Fig. 5). King Erik died only two years later and the unity of the realm was once more restored. ${ }^{5}$

The partitions of 1310 and 1357 are illustrative of the special role of Finland - separated geographically from the rest of the realm by the Sea of Bothnia - within the fiscal system throughout the Middle Ages. It was often maintained as one single entity and repeatedly given a single grantee, as it was in 1310 and in 1357. Similarly, all of Finland was given as one single fief to Karl Knutsson (Bonde) after he had resigned as a king in 1457; the same happened with Sten Sture the Elder when he resigned as national director in 1497, as well as with King Gustav Vasa's son Johan (later King Johan III), who was named Duke of Finland in 1556. Although neither Karl Knutsson nor Sten Sture were endowed with the title of duke, their extensive fiefdoms in Finland can certainly be seen as very generous territorial pensions similar to the ones given to the dukes in the early $14^{\text {th }}$ century and King Magnus in the middle of the century. To some extent the enfeoffments can also be seen as a 'dry guillotine,' i.e. a way for their successors to effectively get rid of dangerous potential rivals by removing them from the center political stage, in an ostensibly generous gesture. Thus, on repeated occasions in the 1310s, the 1350s and in the late 1400s, Sweden ran a real risk of feudal dissolution but eventually escaped it.

\footnotetext{
${ }^{5}$ B. Fritz, op. cit., vol. 1, pp. 89-90.
} 

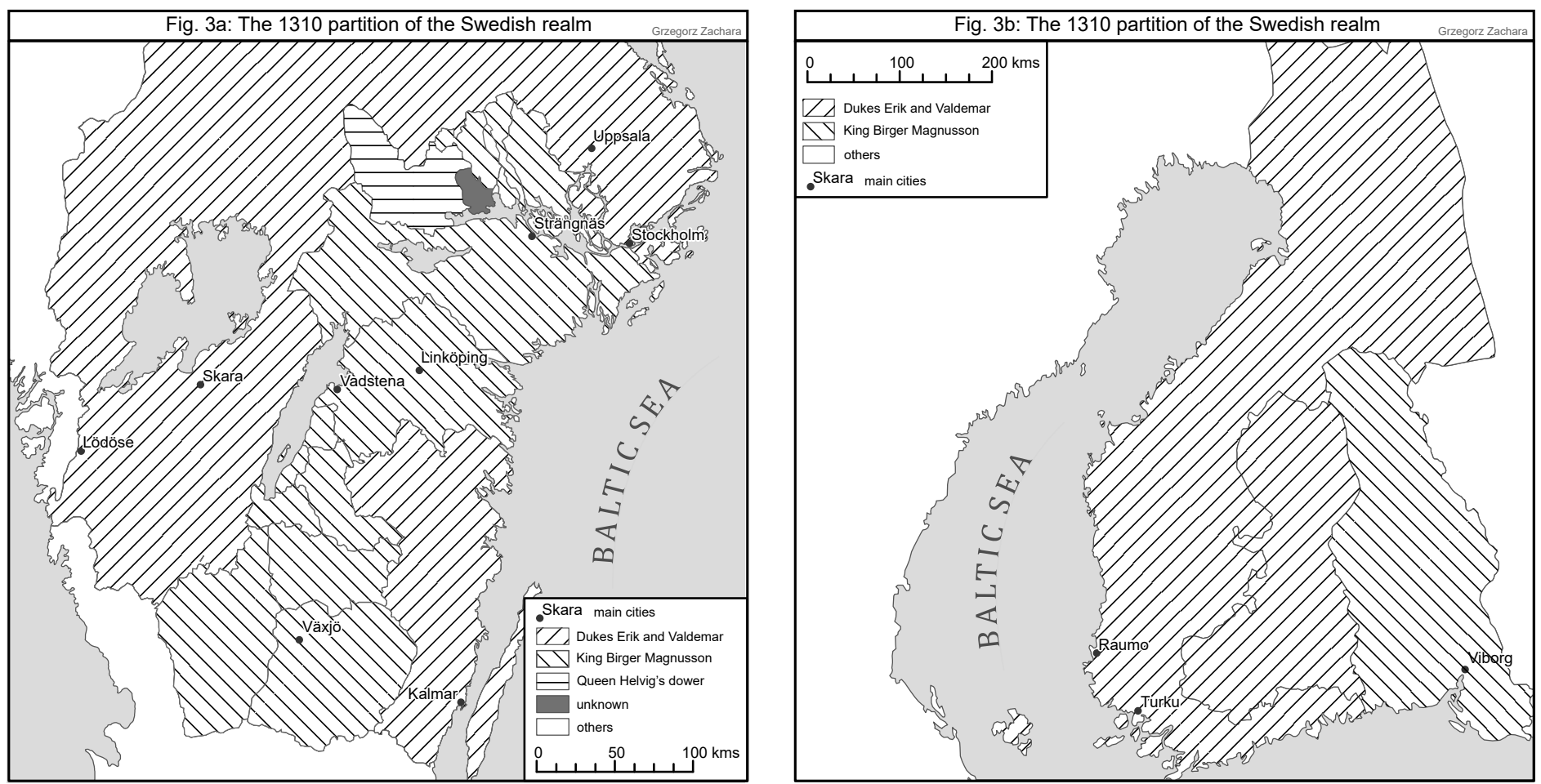

Fig. 3. The 1310 partition of the Swedish realm 

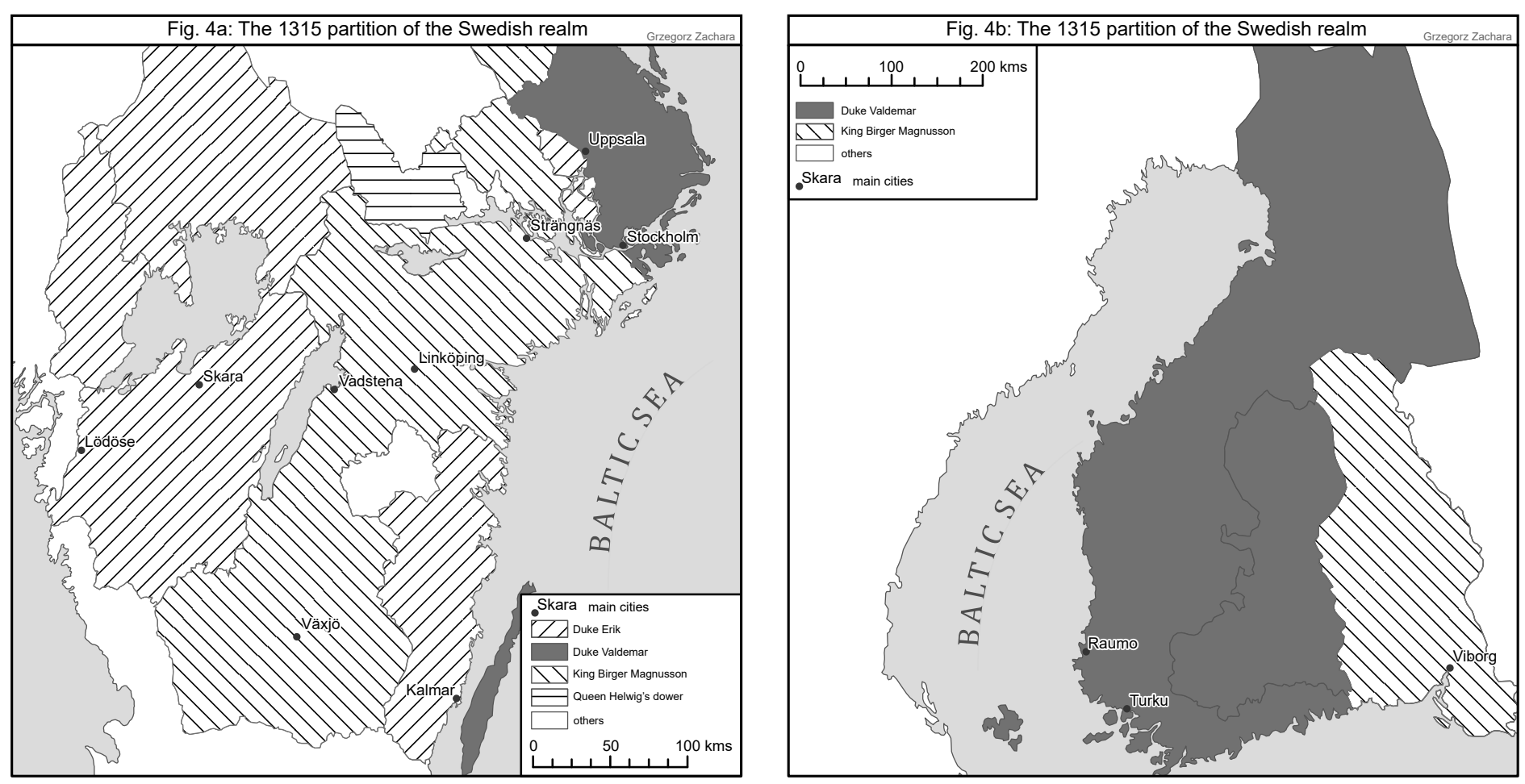

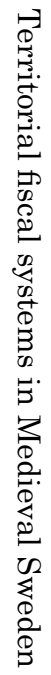

Fig. 4. The 1315 partition of the Swedish realm 

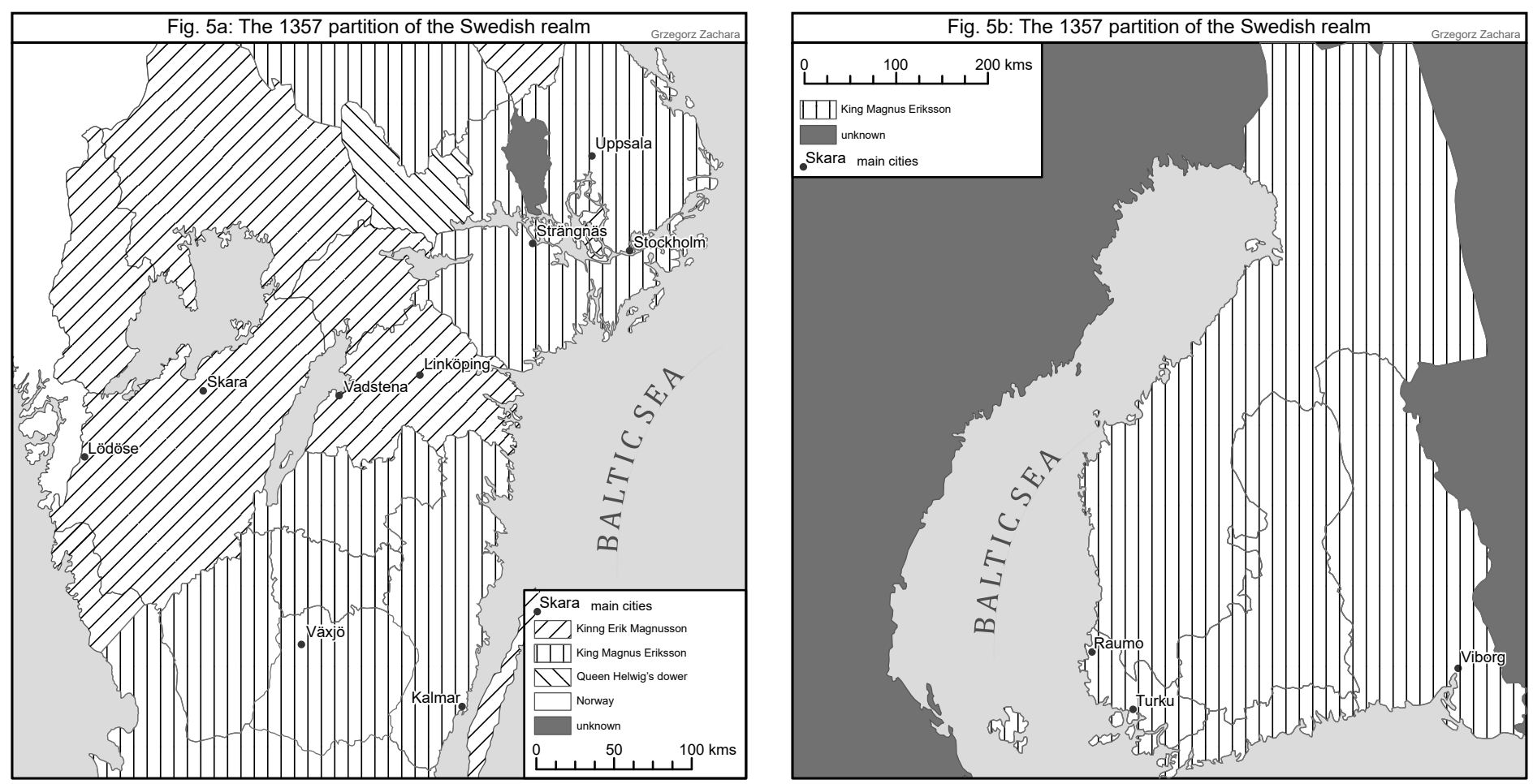

Fig. 5. The 1357 partition of the Swedish realm 


\section{The Evolution of the Territorial Fiscal System}

The first castles to be built in the $13^{\text {th }}$ century - Stockholm, Stäkeborg, Kalmar, Lödöse, Åbo, Tavastehus and Viborg - had truly large tax districts but their exact span is unknown. Birgitta Fritz has argued that the tax districts of Axvall and Lödöse alone must have originally covered the entire western part of the country and that the castles built on their territory at a later stage were detached from it. ${ }^{6}$ However, that is not at all certain. Given the rudimentary character of the territorial system at this early stage, it is more probable that the territorialization of taxes expanded gradually and that new regions were included in the territorial organization for the first time as new castles were built in the following century.

Thus, the expansion of the territorial tax system in the course of the $14^{\text {th }}$ century was carried out through the formation of new tax districts either around new-built castles or large estates within the existing units, including some of the pre- $13^{\text {th }}$ century royal estates, or in new regions. Some of the castles seem to have been abandoned already by the first years of the 1400s, for example Lindholm, Lödöse, Stynsborg and Styresholm, which meant that some tax districts ended up with no geographical center at all. Still, by 1434 the total number of castles as centers of tax districts had reached thirty-six.

However, the same year a major violent uprising broke out under the leadership of Engelbrekt Engelbrektsson. ${ }^{7}$ In the course of the twoyear long uprising, a number of castles were burnt and destroyed forever by the rebel forces. That was the case with Piksborg, Trolleborg, Amneholm, Opensten, Dalaborg, Edsholm, Köpingshus, Borganäs and Faxeholm. Most of these castles were situated in the areas bordering Denmark in the south and the west or in the mining area of central Sweden, where the uprising started and gained its most intensive force. Others escaped destruction but were subsequently abandoned or lost their role in the fiscal organization (Östhammar, Gripsholm, Täljehus, Ekholm, Sundholm, Öresten), while Almarestäket was destroyed, rebuilt and later regained its position as a tax center. Seven of the remaining twenty castles were destroyed in several wars with Denmark and in domestic conflicts between 1469 and 1520 (Ringstadaholm, Rumlaborg,

${ }^{6}$ B. Fritz, op. cit., vol. 2, pp. 64-65. See also E. Lönnroth, Statsmakt och statsfinans i det medeltida Sverige: Studier över skatteväsen och länsförvaltning, Göteborg, 1940, p. 137.

7 On the uprising in general, see P. Reinholdsson, Uppror eller resningar? Samhällsorganisation och konflikt $i$ senmedeltidens Sverige, Uppsala, 1998. 
Axvall, Älvsborg, Öresten, Stäkeholm, Almarestäket). Only one new castle was built after 1434 - Olofsborg (1475) in faraway Savolaks, close to the Russian border. As a result, already by 1502 the large province of Västergötland and large parts of the Småland province had no castle at all, and by 1520 the total number of castles in the realm had been reduced to fourteen, with only seven in Sweden proper.

In the case of the castles which were not rebuilt after the 1434-1436 uprising, their tax districts were maintained as separate units. At the same time, the process of fragmentation of the remaining tax districts continued through increased enfeoffments of hundreds (härader) and parishes detached from the castle districts they had originally belonged to. The main driving forces behind this process of fragmentation were of economic and political nature. Firstly, the reduced number of castles naturally freed disposable resources for other purposes. Secondly, the new situation after the uprising resulted in the regents having an increasing need to reward political support. The basic principle here was to grant political followers tax incomes from the tax district surrounding their main manor (sätesgård). That tendency was most clearly seen in the provinces of Uppland, Södermanland, Östergötland, and in particular in Småland and Västergötland, where härad fiefs came to predominate, except for the core areas around the remaining castles. The tax districts under the Borgholm and Örebro castles were kept intact. Likewise, in the sparsely populated areas in northern Sweden and in Finland, the fragmentation of existing tax districts was virtually non-existent, with a partial exception for southwestern Finland, although even there parish fiefs are documented to have emerged in the early $16^{\text {th }}$ century for the first time ever, evidencing the general tendency. ${ }^{8}$

\section{The Evolution of the Fiscal Organization}

A detailed study of the development of state finances in medieval Sweden still remains to be conducted. Although the amount of documentary records from the Swedish Middle Ages is relatively small, in particular records that contain quantitative data, there are good possibilities for such a study. For example, there are three medieval tax registers, dated 1413, 1497 and ca. 1512. They contain information about tax revenues, the geographical configuration of the tax districts

\footnotetext{
${ }^{8}$ D. Retsö, Länsförvaltningen..., pp. 311-313.
} 
as well as their administrative form (i.e. whether administered by the Crown or by a fiefholder) and, in some cases, the number of taxed peasants, which makes it possible to calculate tax per freeholder. ${ }^{9}$ Taxes are expressed both in money sums and quantities of taxes in kind, which makes it possible to identify regional specialities, such as cattle from the province of Västergötland and the southwestern part of Småland, grain from the Mälaren valley and iron from Dalarna. Furthermore, the taxes in kind are possible to translate into sums of money thanks to the information on contemporary market prices of goods and also in real terms as the real silver value in medieval Swedish coins. ${ }^{10}$ Unfortunately, these registers are not uniform and none is complete, which in part is explained by the fact that they were created with different purposes. For example, the 1413 register was drawn up on the initiative of King Erik, whereas the 1497 and 1512 registers were probably made by members of the council of the realm. That means that they all may contain biases, e.g. in the latter cases the tax sums for tax districts that were sought after as fiefs may be underestimated, and vice versa. As for quantitative data, the 1497 register is the most complete, with rents mentioned for 61 out of all 172 counties and with a number of towns and parishes provided. In total, fiscal data from 109 counties has been preserved, including additional evidence dispersed in a number of account books, charters and letters with similar information which gives a reasonably good picture of the evolution of the territorial tax system. In addition, there is a number of inventory lists of foodstuffs stored in some castles that may serve to estimate taxes in kind. ${ }^{11}$ Far richer source material is available from the 1530 s and the $1540 \mathrm{~s}^{12}$

The evolution of the financial policies of the Swedish Crown is closely tied to the development of the territorial tax system, and both originated in the political and military development. The period between the mid-1200s and the early 1500s can be divided into five distinct periods

9 The registers printed in Das Steuerbuch König Eriks XIII: Versuch einer Rekonstruktion, ed. O. Bjurling, Lund, 1962; G. T. Westin, "De s. k. länsregistren från medeltidens slut," Scandia 21, 1951-1952, pp. 125-196; and in Retsö, Länsförvaltningen..., pp. 396-410.

${ }^{10}$ Unpublished data base and R. Edvinsson, B. Franzén, J. Söderberg, "Swedish Payment Systems 995-1534," in: Historical Monetary and Financial Statistics for Sweden: Exchange Rates, Prices and Wages, 1277-2008, eds. R. Edvinsson, T. Jacobsson, D. Waldenström, Stockholm, 2010, pp. 67-132.

${ }^{11}$ D. Retsö, "Between Frugality and Prosperity: Standard of Living and Consumption Patterns of Castle Personnel in Early $16^{\text {th }}$ Century Sweden," The Journal of European Economic History 45, 2017, pp. 143-175.

${ }^{12}$ See F. Dovring, De stående skatterna på jord 1400-1600, Lund, 1951. 
during which the Crown would resort to a whole array of available mechanisms for raising its revenues or reducing its costs.

Period 1 (c. 1250-1332). As it has been mentioned, the first half of the $14^{\text {th }}$ century was dominated by rivalry and civil wars between members of the royal family. But already towards the late 1200s, domestic and international events raised the Crown's military expenses. At the same time, the purchase of taxed land by the nobility increased and transformed it into tax-exempt land, thus further lowering potential tax revenues, a tendency fought in vain by the Crown, which instead tried to resort to extra taxes. Since these were imposed on the nobility too, the nobles expectedly tried, successfully so, to include a prohibition against extra taxes in the Law of the Realm that came into force in the $1330 \mathrm{~s}$. By the beginning of the $14^{\text {th }}$ century it was evident that there was an imbalance between the needs of the military and the financial resources to meet them. Sweden had imported novelties from abroad - continental feudal institutions like an armed class of nobles and military institutions like fortified castles and, later, mercenary soldiers - for which the economic base was not prepared. Under normal circumstances there was a possibility to achieve, if not a net surplus, at least a budget balance, but at any military pressure the finances would become financially untenable and an urgent need for cash through loans appeared. The result was a cumulative budget deficit for the Crown.

Period 2 (1332-1397). Predictably, the second period was therefore characterized by the Crown's attempts to finance its expenses from sources other than taxes. The Great Plague, which reached Sweden in 1350 , made it even more unrealistic to find revenue through taxes from an already sharply declined population. True, there was a remarkably high seigniorage rate during the second half of the $14^{\text {th }}$ century..$^{13} \mathrm{But}$ the most important alternative chosen was loans. The Crown borrowed extensively from the Church, great landowners, domestic and foreign merchants, and foreign princes. Pledges for these loans were often territorial incomes and taxes from royal estates, which only led to further depletion of resources and less possibilities to redeem the collateral. Eventually, most of the tax districts in the realm were enfeoffed and only a small part was at the Crown's direct disposal. This was especially the case under King Magnus Eriksson, who had to redeem not only loans contracted by his father and uncle, but also a high dower for his sister's marriage and the provinces of Blekinge, Skåne and Halland from Denmark (to a total sum of 34,000 marks, equivalent to almost one

\footnotetext{
${ }^{13}$ R. Edvinsson et al., "Swedish...," p. 103.
} 
and a half ton of silver). ${ }^{14}$ Towards the end of the period, the relatively low tax level also began to rise. ${ }^{15}$ As the financial crisis was reaching its peak and the realm seemed to be heading for fragmentation, the first method chosen to solve the political situation was to invite foreign princes to govern the country, and in 1365, Albrekt of Mecklenburg from northern Germany was crowned King of Sweden. With Albrekt there were beginnings of a stabilization of the situation. For example Bo Jonsson (Grip), one of the greatest magnates of the time, redeemed pledges and thus became a large fief-holder, but according to his will the property was eventually returned to the Crown. ${ }^{16}$

Period 3 (1397-1434). Financing the Crown through loans was a dead-end street and was only practiced to a limited extent hereafter. What followed instead was a period of raised taxes, both ordinary and extraordinary, as well as redemption of fiefs and acquired taxexempt land. These measures of centralization and effectivization also coincided with the establishment of the Kalmar Union in 1397, which included the greatly weakened Swedish kingdom. Officially a personal union between three equal kingdoms (Sweden, Denmark, Norway), it was ultimately perceived as an instrument for Danish dominance. King Erik of Pomerania, king in all three Scandinavian kingdoms, clearly sought to impose a strong central state apparatus and somewhat prematurely establish an absolutist state, reducing fiefs and increasing the state revenue through raised taxes. The burden of these tax policies fell entirely on the peasants, who experienced a considerably increased tax pressure. ${ }^{17}$ Additionally, he attempted to debase the currency and raised customs duties. However, the seigniorage rate had been falling since the mid-1300s and continued to do so in the $15^{\text {th }}$ century, and customs duties or net profits from foreign trade were hardly rich sources of income, given the small size of the Swedish towns and the small volume of foreign trade. ${ }^{18}$ At any rate, these financial policies initially bore fruit: the budget deficit was virtually annihilated. But

${ }^{14}$ Ibid., p. 107.

${ }^{15}$ D. Retsö, J. Söderberg, "The Late-Medieval Crisis Quantified: Real Taxes in Sweden, 1320-1550," Scandinavian Economic History Review 40, 2015, no. 1, pp. 1-24.

16 B. Fritz, op. cit., vol. 2, pp. 120-129.

17 E. Lönnroth, op. cit., pp. 176-179; F. Dovring, op. cit., pp. 144-145; D. Retsö, J. Söderberg, op. cit.

${ }^{18}$ For a general overview, see E. F. Heckscher, An Economic History of Sweden, Cambridge, MA, 1963, pp. 17-60. See also I. Hammarström, Finansförvaltning och varuhandel 1504-1540: Studier i de yngre Sturarnas och Gustav Vasas statshushållning, Uppsala, 1956, pp. 170-174. 
it was achieved to the price of declining living standards of the peasants, who had benefited from declining land rents and prices and rising wages following the Great Plague. ${ }^{19}$ Beside an improved financial situation, King Erik's centralist policies had another, quite natural but disastrous consequence. In 1434, the Engelbrekt rebellion carried out by overburdened tax-paying peasants and tax-hungry nobles broke out.

Period 4 (1434-1470). The 1434 uprising briefly re-established Swedish autonomy, but it was constantly challenged in the following century by Danish monarchs who from time to time even managed to resurrect the Kalmar Union under their leadership. The union was not definitely broken up until 1523. Most importantly, the uprising stands out in the European perspective as the only one which produced enduring results for the peasants. It marked the beginning of a period during which the regents, in fear of new peasant uprisings, had to accept a permanent lowering of taxes and at the same time satisfy the nobility's thirst for tax incomes and fiefs. ${ }^{20}$ Together with falling prices of taxed items in kind, like butter and oxen, the lower taxes contributed to a higher living standard among peasants. ${ }^{21}$ But to achieve the somewhat contradictory goal of satisfying both sides, the Crown also had to accept grants of fiefs to a large extent, thereby reducing the state revenues considerably. These grants consisted mainly of the tax incomes from the remaining tax districts under direct Crown administration, town taxes and customs duties. On the other hand, the rebellion had also reduced the number of castles, so the financial needs to keep up the castle organization had also diminished. The rebellion had virtually been a drastic and rational, though unintended, budget cut. Loans were rare during this period since the regular taxes that could be used as deposit had diminished due to the enfeoffment of most tax districts and the resulting smaller size of the territory under direct Crown administration. ${ }^{22}$ Lower incomes and lower expenses brought the state budget to a balance but at a lower level than before. The rebellion had shown

${ }^{19}$ J. Myrdal, "The Forgotten Plague: The Black Death in Sweden," in: When Disease Makes History: Epidemics and Great Historical Turning Points, ed. P. Hämäläinen, Helsinki, 2006, p. 155; id., "Scandinavia," in: Agrarian Change and Crisis in Europe, ed. H. Kitsikopoulos, New York, 2012, pp. 213-214, 228.

20 J. Myrdal, "Scandinavia," pp. 213-214. The new tax level was codified in the Strängnäs statute in March 1437, Privilegier, resolutioner och förordningar för Sveriges städer, Del 1 (1251-1523), ed. N. Herlitz, Stockholm, 1927, no. 80.

${ }^{21}$ J. Söderberg, "Prices and Economic Change in Medieval Sweden," Scandinavian Economic History Review 55, 2007, pp. 143-146, 148.

${ }^{22}$ See I. Hammarström, op. cit., pp. 67-69. 
that the reduction of seignorial land through recentralization was, for political reasons, as impossible as real increases of the regular taxes; the former was resisted by the nobility, the latter by the peasantry.

Period 5 (1470-1520) has, in previous research, been held out as a gradual return of centralist tendencies. ${ }^{23}$ Some attempts to raise or transform extra taxes into - regular taxes were indeed made in last decades of the $15^{\text {th }}$ century and some fiefs were redeemed. But the net effect of these policies was modest or even null, since tax raises were efficiently opposed by the peasantry and the recentralization of some tax districts was compensated by enfeoffments of others. ${ }^{24}$ The policy was in fact even more refined than that and executed in quite an intelligent way. Tax districts with a low level of productivity or with a large share of tax-exempt land were widely granted as fiefs while relatively rich tax districts - i.e. tax districts with a high level of productivity or with a small share of tax-exempt land - were kept under direct Crown administration. Thus, it was not a question of centralization per se but a restructuring of Crown-administered tax territory. For example, it is conspicuous that the rich mining areas of Västmanland and Dalarna as well as the cattle-raising districts in southwestern Småland were purposefully held under Crown administration. This strategy accomplished three goals: Crown revenues could be kept constant and even rising, the general low tax level could be maintained for the benefit of the peasants, and the thirst for extensive fiefs to the nobility could be satisfied. Both goals served the Crown, since political calm was maintained and the period between 1471 and 1497 was indeed marked by a remarkably long peace. In addition, two other means of generating revenue seem to have become more important than before during this period; the use of private incomes in public finances and the commercialization of the domestic and international markets of taxes in kind. As for the former method, it seems that a larger share of private income than before was used by the regents to fill the needs of public finances to some extent. The use of non-fiscal revenue certainly became more common in the early modern period, but first attempts towards it had already been made at the end of the Middle Ages. ${ }^{25}$ It was enhanced by the fact that during most of the period, except for 1497-1501, Sweden

${ }^{23}$ E. Lönnroth, op. cit., pp. 242-250.

${ }^{24}$ D. Retsö, "No Taxation without Negotiation: War Economy, Taxes and the Peasantry in Sweden in Early 16th Century," Scandinavian Journal of History 42, 2017, pp. 439-458; id., Länsförvaltningen..., pp. 365-370.

${ }^{25}$ For early modern Sweden, see K. Nilsson, The Money of Monarchs: The Importance of Non-Tax Revenue for Autocratic Rule in Early Modern Sweden, Lund, 2017. 
was governed by a national director (riksföreståndare) who in effect was a sui generis viceroy and who, in his capacity as a member of the council of the realm, held fiefs of his own and whose resources were regarded to be at his disposal for public purposes. As for the commercialization of taxes in kind, it had excellent prospects in Sweden's close trade relations with the towns of the Hanseatic League, especially Lübeck, and is evidenced by the implementation of proto-mercantilist measures like bullionist policies and the staple regulations of the 1490s. Yet, it seems that the Crown's share in the export of Sweden's main export item, iron, was only some $10 \%{ }^{26}$

Table 1: Overview of the fiscal system in medieval Sweden

\begin{tabular}{|l|l|l|l|l|l|}
\hline \multicolumn{1}{|c|}{ Period } & $\begin{array}{c}\text { Administra- } \\
\text { tive system }\end{array}$ & \multicolumn{1}{|c|}{ Revenue system } & \multicolumn{1}{|c|}{$\begin{array}{c}\text { State } \\
\text { budget }\end{array}$} & $\begin{array}{c}\text { Territorial } \\
\text { system }\end{array}$ & $\begin{array}{c}\text { Tax } \\
\text { level }\end{array}$ \\
\hline c. $1250-1332$ & centralized & extra taxes & $\begin{array}{l}\text { growing } \\
\text { deficit }\end{array}$ & $\begin{array}{l}\text { castle tax } \\
\text { districts }\end{array}$ & low \\
\hline $1332-1397$ & decentralized & loans, fiefs & great deficit & $\begin{array}{l}\text { castle tax } \\
\text { districts }\end{array}$ & high \\
\hline $1397-1434$ & centralized & $\begin{array}{l}\text { raised taxes, redemp- } \\
\text { tion of acquired tax- } \\
\text { exempt land (and } \\
\text { currency debase- } \\
\text { ment, raised customs } \\
\text { duties) }\end{array}$ & balanced & $\begin{array}{l}\text { castle tax } \\
\text { districts }\end{array}$ & high \\
\hline $1434-1470$ & decentralized & $\begin{array}{l}\text { lower regular taxes, } \\
\text { town taxes, customs } \\
\text { duties }\end{array}$ & $\begin{array}{l}\text { balanced at } \\
\text { a lower level }\end{array}$ & $\begin{array}{l}\text { small tax } \\
\text { districts }\end{array}$ & low \\
\hline $1470-1520$ & $\begin{array}{l}\text { selective decen- } \\
\text { tralization }\end{array}$ & $\begin{array}{l}\text { regular taxes, private } \\
\text { incomes, commercial- } \\
\text { ization of taxes in } \\
\text { kind }\end{array}$ & $\begin{array}{l}\text { balanced at } \\
\text { a rising level }\end{array}$ & $\begin{array}{l}\text { small tax } \\
\text { districts }\end{array}$ & low \\
\hline
\end{tabular}

It can be added that King Gustav Vasa (1523-1560) took to a solution to the financial strains of the Crown that had never really been tried before. Instead of seeking compensation for the Crown expenses with reluctant noblemen and rebellious peasants, he attacked the one institution that had escaped all financial strain until now - the Church. In 1527, he broke with the Roman Catholic church, established a national Swedish church organization and confiscated all church-owned land

${ }^{26}$ D. Retsö, Länsförvaltningen..., pp. 38-42; I. Hammarström, op. cit., pp. 103$-122,167-188$. For Sweden's trade relations with the Hanseatic League in general, see S. Lundkvist, "Schweden und die Hanse: Handel und Macht im Ostseeraum," in: Schweden und Deutschland: Begegnungen und Impulse, ed. M. Grass, Stockholm, 1999, pp. 27-38. 
almost overnight. That enabled him to avoid offending any important social group and leave the proportions of both tax-exempt land and taxdue land intact, thus securing both domestic peace and a considerable rise in Crown revenues. In the long run, taxes were indeed slowly raised and extra taxes were introduced, spurring, in the course of the $16^{\text {th }}$ century, the most violent peasant rebellions since 1434, but this time the uprisings proved unsuccessful. By 1535, the Crown was debt-free. ${ }^{27}$

\section{Conclusion}

The territorial tax system was established in Sweden gradually from the $13^{\text {th }}$ century and reached its maximum scope by 1434 . The original organization was built up around royal castles; enfeoffments were rare. This Crown-dominated fiscal organization began to break up already towards the end of the $13^{\text {th }}$ century. By the middle of the $15^{\text {th }}$ century the number of castles had diminished and large castle districts had been split up into smaller ones.

Five periods of fiscal policies can be discerned and differentiated with regard to the sources of revenue, degrees of centralization, territorial organization, tax levels and effects on the state budget. The first period, extending to the 1330s, was characterized by a centralized administrative system based on royal castle tax districts, a growing deficit financed by extra taxes but with a still relatively low total tax level. It was followed by a period of a growing budget deficit financed by loans and a rising tax level. In the first decades of the $15^{\text {th }}$ century the tax level reached very high levels; the period also saw the redemption of fiefs, which led to an improved budget situation but also to increased discontent among both the nobility and the peasantry. In 1434, an inter-class revolt managed to bring down taxes and to bring back fief incomes to the nobility to levels that would persist for the rest of the Middle Ages. In the last half-century a refined version of this tax strategy was practiced: relatively rich tax districts were kept under Crown administration and poorer ones were enfeoffed, while tax levels were kept on a constant level. The result were slowly rising incomes and relative political stability.

${ }^{27}$ At first, a futile attempt to curb the Church financially was made by King Karl Knutsson in 1453-1454, see C. G. Andrae, "Karl Knutssons räfst 1453-1454," in: Ny väg till medeltidsbreven, eds. C. Gejrot, R. Andersson, K. Abukhanfusa, Stockholm, 2002, pp. 245-257. 


\section{Bibliography}

Andrae C.G., "Karl Knutssons räfst 1453-1454," in: Ny väg till medeltidsbreven, eds. C. Gejrot, R. Andersson, K. Abukhanfusa, Stockholm, 2002, pp. 245-257.

Dovring F., De stående skatterna på jord 1400-1600, Lund, 1951.

Edvinsson R., Franzén B., Söderberg J., "Swedish Payment Systems 995-1534," in: Historical Monetary and Financial Statistics for Sweden: Exchange Rates, Prices and Wages, 1277-2008, eds. R. Edvinsson, T. Jacobsson, D. Waldenström, Stockholm, 2010, pp. 67-132.

Fritz B., Hus, land och län: Förvaltningen i Sverige 1250-1434, vol. 1-2, Stockholm, 1972-1973.

Hammarström I., Finansförvaltning och varuhandel 1504-1540: Studier i de yngre Sturarnas och Gustav Vasas statshushållning, Uppsala, 1956.

Heckscher E.F., An Economic History of Sweden, Cambridge, MA, 1963.

Lindkvist Th., "Taxation Systems in Medieval Sweden," in: Taxes, Tributes and Tributary Lands in the Making of Scandinavian Kingdoms in the Middle Ages, ed. S Imsen, Trondheim, 2011, pp. 265-278.

Lönnroth E., Statsmakt och statsfinans $i$ det medeltida Sverige: Studier över skatteväsen och länsförvaltning, Göteborg, 1940.

Lovén Ch., Borgar och befästningar i det medeltida Sverige, Stockholm, 1996.

Lundkvist S., "Schweden und die Hanse: Handel und Macht im Ostseeraum," in: Schweden und Deutschland: Begegnungen und Impulse, ed. M. Grass, Stockholm, 1999, pp. 27-38.

Myrdal J., "The Forgotten Plague: The Black Death in Sweden," in: When Disease Makes History: Epidemics and Great Historical Turning Points, ed. P. Hämäläinen, Helsinki, 2006, pp. 141-186.

Myrdal J., "Scandinavia," in: Agrarian Change and Crisis in Europe, ed. H. Kitsikopoulos, New York, 2012, pp. 204-249.

Nilsson K., The Money of Monarchs: The Importance of Non-Tax Revenue for Autocratic Rule in Early Modern Sweden, Lund, 2017.

Palme S.U., "Les impôts, le statut d'Alsnö et la formation des ordres en Suède (1250-1350)," in: Problèmes de stratification sociale: Actes de colocque (1966), ed. R Mousnier, Paris, 1968, pp. 55-71.

Privilegier, resolutioner och förordningar för Sveriges städer, Del 1 (1251-1523), ed. N. Herlitz, Stockholm, 1927.

Reinholdsson P., Uppror eller resningar? Samhällsorganisation och konflikt $i$ senmedeltidens Sverige, Uppsala, 1998.

Retsö D., "Between Frugality and Prosperity: Standard of Living and Consumption Patterns of Castle Personnel in Early $16^{\text {th }}$ Century Sweden," The Journal of European Economic History 45, 2016, pp. 143-175.

Retsö D., Länsförvaltningen i Sverige 1434-1520, Stockholm, 2009.

Retsö D., "No Taxation without Negotiation: War Economy, Taxes and the Peasantry in Sweden in Early $16^{\text {th }}$ Century," Scandinavian Journal of History 42, 2017, pp. 439-458. 
Retsö D., Söderberg J., "The Late-Medieval Crisis Quantified: Real Taxes in Sweden, 1320-1550," Scandinavian Economic History Review 40, 2015, no. 1, pp. 1-24.

Söderberg J., "Prices and Economic Change in Medieval Sweden," Scandinavian Economic History Review 55, 2007, pp. 128-152.

Das Steuerbuch König Eriks XIII: Versuch einer Rekonstruktion, ed. O. Bjurling, Lund, 1962.

Westin G.T., "De s. k. länsregistren från medeltidens slut," Scandia 21, 1951-1952 , pp. 125-196.

Dag Retsö

Territorial fiscal systems in Medieval Sweden (Summary)

When a territorial fiscal organization centered around castles was established in Sweden in the $13^{\text {th }}$ century it initially strengthened the Crown's finances. But the system was to an increasing extent hollowed out by grants of Crown taxes through fiefs to the warrior élite and tax exemption on privately owned land. Over time, two distinct patterns evolved. On the one hand persistent budget deficits in the central finances forced the Crown to implement a variety of financing devices, including loans, extra taxes, redemption of tax-exempt land and commercialization of taxes in kind. On the other hand, the territorial organization underwent a process of fragmentation, where fiscal units were becoming smaller and smaller, a tendency enforced by the destruction of many castles during the Engelbrekt peasant uprising in 1434-1436. The rebel peasants were successful in achieving a substantial lowering of the tax burden. Thus, together with the diminished number of castles, it led to a situation of both lower costs and lower revenues for the Crown. These two processes led to introducing a financial strategy towards the end of the $15^{\text {th }}$ century where the Crown managed to strike a balance between financial strains and political pressures - from the nobility for fiefs as well as from the peasantry for the continuation of low taxes. The result was a selective fief policy where rich tax districts were reserved for the Crown while less affluent districts were generously given as fiefs.

Dag Retsö - profesor nadzwyczajny historii gospodarczej na Wydziale Historii Gospodarczej i Stosunków Międzynarodowych Uniwersytetu w Sztokholmie. Jego zainteresowania naukowe obejmują warunki życiowe, systemy skarbowe i mobilność geograficzną w średniowieczu, a także badania nad klimatem w perspektywie historycznej. 
Dag Retsö - associate professor in economic history at the Department of Economic History and International Relations, Stockholm University. His scientific interests include living standards, fiscal organization and geographical mobility in the Middle Ages, as well as historical climatology.

E-mail: dag.retso@ekohist.su.se. 